\title{
OPTIMASI BOBOT K-MEANS CLUSTERING UNTUK MENGATASI MISSING VALUE DENGAN MENGGUNAKAN ALGORITMA GENETIKA
}

\author{
Bain Khusnul Khotimah" ${ }^{* 1}$, Muhammad Syarief ${ }^{2}$, Miswanto $^{3}$, Herry Suprajitno ${ }^{4}$ \\ 1,2 Jurusan Teknik Informatika, Universitas Trunojoyo Madura, Indonesia \\ ${ }^{3,4}$ Departmen Matematika, Universitas Airlangga Surabaya, Indonesia \\ 1'bain@trunojoyoac.id; ${ }^{2}$ mohammad.syarief@trunojoyo.ac.id; ${ }^{3}$ miswanto@ fst.unair.ac.id; \\ ${ }^{4}$ herry-s@fst.unair.ac.id \\ *Penulis Korespondensi
}

(Naskah masuk: 09 April 2021, diterima untuk diterbitkan: 19 Juli 2021)

\begin{abstract}
Abstrak
Nilai yang hilang membutuhkan preprosesing dengan teknik imputasi untuk menghasilkan data yang lengkap. Proses imputasi membutuhkan initial bobot yang sesuai, karena data yang dihasilkan adalah data pengganti. Pemilihan nilai bobot yang optimal dan kesesuaian nilai $K$ pada metode $K$-Means Imputation (KMI) merupakan masalah besar, sehingga menimbulkan error semakin meningkat. Model gabungan algoritma genetika (GA) dan KMI atau yang dikenal GAKMI digunakan untuk menentukan bobot optimal pada setiap cluster data yang mengandung nilai yang hilang. Algoritma genetika digunakan untuk memilih bobot dengan menggunakan pengkodean bilangan riel pada kromosom. Model hybrid GA dan KMI dengan pengelompokan menggunakan jumlah jarak Euclidian setiap titik data dari pusat clusternya. Pengukuran kinerja algoritma menggunakan fungsi kebugaran optimal dengan nilai MSE terkecil. Hasil percobaan data hepatitis menunjukkan bahwa GA efisien dalam menemukan nilai bobot awal optimal dari ruang pencarian yang besar. Hasil perhitungan menggunakan nilai $\mathrm{MSE}=0.044$ pada $\mathrm{K}=3$ dan replika ke- 5 menunjukkan kinerja GAKMI menghasilkan tingkat kesalahan yang rendah untuk data hepatitis dengan atribut campuran. Hasil penelitian dengan menggunakan pengujian tingkat imputasi menunjukkan algoritma GAKMI menghasilkan nilai $r=0.526$ lebih tinggi dibandingkan dengan metode lainnya. Penelitian ini menunjukkan GAKMI menghasilkan nilai r yang lebih tinggi dibandingkan metode imputasi lainnya sehingga dianggap paling baik dibandingkan teknik imputasi secara umum.
\end{abstract}

Kata kunci: hybrid GA K-Means, optimasi bobot, missing value, MSE, imputasi data, K-Means Imputation

\section{OPTIMIZATION WEIGHT OF K-MEANS CLUSTERING TO OVERCOME MISSING VALUE USING GENETIC ALGORITHM}

\begin{abstract}
Missing values require preprocessing techniques as imputation to produce complete data. Complete data imputation results require the appropriate initial weights, because the resulting data is replacement data. The choice of the optimal weighting value and the suitability of the network nodes in the K-Means Imputation (KMI) method are big problems, causing increasing errors. The combined model of Genetic Algorithm (GA) and KMI is used to determine the optimal weights for each data cluster containing missing values. Genetic algorithm is used to select weights by using real number coding on chromosomes. GA is applied to the KMI using clustering calculated using the sum of the Euclidean distances of each data point from the center of the cluster. Performance measurement algorithms using the fitness function optimally with the smallest MSE value. The results of the hepatitis data experiment show that GA is efficient in finding the optimal initial weight value from a large search space. The results of calculations using the MSE value $=0.04$ for $K=3$ and the 5th replication. So, GAKMI resulted in a low error rate for mixed data. The results of research using imputation level testing performed GAKMI produced $r=0.526$ higher than the other methods. Thus, the higher the $r$ value, the best for the imputation technique.
\end{abstract}

Keywords: GA, K-Means, weight optimization, missing value, MSE, imputation

\section{PENDAHULUAN}

Mekanisme imputasi (Acuna, 2004, Anwar, 2019). Mekanisme imputasi dilakukan dengan memprediksi nilai yang hilang dengan cara tertentu, yang hasilnya digunakan sebagai nilai pengganti (Han, 2010, Enders, 2014). K-Means untuk mengatasi 
data yang hilang dikenal dengan $K$-Means Imputation (KMI) (Li, 2004, Mahboob, 2018). KMI adalah salah satu metode clustering untuk mengelompokkan data yang polanya belum diketahui. Proses imputasi KMI sangatlah menarik, ketika berhadapan dengan keragaman dan ketidakpastian data sehingga fitur pembelajaran membutuhkan data lengkap untuk menghasilkan kenerja yang baik (Zeebaree, 2017, Anwar, 2019).

K-Means secara umum memerlukan optimasi untuk menentukan pembaruan bobot baru, yang dapat meningkatkan efisiensi pembelajaran dan menyesuaikan nili $k$. K-Means memiliki kelemahan yaitu adanya ketidakkonsistenan initial $k$, bobot awal yang berbeda setiap iterasi, dan penggunaan parameter lainnya. K-Means ketika menentukan bobot awal acak seringkali menyebabkan dua kelemahan utama yaitu terjebak dalam minima lokal dan konvergen menjadi lebih lambat (Zeebaree, 2017). K-Means membutuhkan algoritma optimasi untuk memperbaiki kualitas parameter yang digunakan. Algoritma ini melibatkan fungsi dinamis untuk satu set parameter yang mengarah pada peningkatan kinerja clustering ((Farag, 2015a). Metode pengelompokan baru dipasangkan dengan pendekatan global untuk mengelola stabilitas lokal (Binu, 2015).

$K$-Means mengklasifikasikan data berdasarkan cluster titik tengah (centroid). Ketika centroid awal diinisialisasi secara acak dan terus diperbarui sampai mendapatkan cluster secara optimal. Proses inisialisasi centroid pada metode $K$-Means sangat mempengaruhi hasil cluster. GA diusulkan untuk mengatasi masalah sensitivitas dalam inisialisasi sentroid (AL Malki, 2016, Khotimah, 2016). Penelitian yang menunjukkan efektifitas GA dalam optimalisasi cluster menunjukkan bahwa algoritma genetika efektif dalam menangani data dengan atribut campuran pada jumlah cluster tertentu (Farag, 2015, Kaczmarowski, 2015, Chehouri, 2017). Sedangkan algoritma genetika dan algoritma $K$-Means and kMedoids pada data beratribut campuran digunakan untuk memperoleh solusi optimum global sehingga hasil pengclusteran menjadi lebih baik dan akurat (Islam, 2020).

Permasalahan K-Means Imputation dalam memilih nilai bobot optimal merupakan masalah besar, karena nilai bobot sangat mempengaruhi hasil estimasi ketika proses imputasi. Penggunaan pola bobot yang konstan pada saat pengisian data, seringkali menjadi kesalahan besar dalam proses meminimalkan cluster karena nilai data yang kurang beragam (Maulik, 2000, Rahman, 2014, Anwar, 2019).

Penelitian ini mengembangkan model pencarian bobot optimal KMI pada kasus data yang hilang dengan menggunakan algoritma genetika. GA pada KMI dilatih untuk menggunakan algoritma genetika untuk menyesuaikan bobot dan bias di setiap lapisan. GA yang menggunakan analisis clustering untuk mengatur populasi dan memilih orang tua untuk rekombinasi. sehingga hasil akhir kinerja clustering dipakai untuk menghitung fungsi kebugaran. Clustering pada data yang hilang seringkali terjadi diberbagai bidang yaitu teknik dan disiplin ilmu seperti biologi, kedokteran, pembelajaran mesin, pengenalan pola, analisis citra dan industri.

Algoritma GA-KMI digunakan untuk mencari bobot pusat cluster dengan meminimalkan metrik pengelompokan. Pencarian bobot optimal pada KMI melalui algoritma genetika. Analisis clustering diterapkan untuk menyesuaikan probabilitas crossover Pc dan mutasi Pm dalam GA. Dengan menerapkan algoritma K-Means, populasi dikelompokkan dalam setiap generasi untuk menyesuaikan nilai-nilai operator genetik. Peraturan didasarkan pada mempertimbangkan ukuran relatif antara cluster masing-masing memegang kromosom terbaik dan terburuk. Kromosom terbaik adalah kromosom yang dihasilkan untuk menyelesaikan masalah pada berbagai banyak objektif variabel keputusan. Penelitian ini menggunakan studi kasus Hepatitis C terhadap 155 pasien dengan 19 fitur campuran kategori dan kontinu, yang telah diambil dari pembelajaran mesin gudang Universitas California. Masalah tingkat Bilirubin dalam hepatitis merupakan atribut kontinu, atribut yang diambil berdasarkan gejal merupakan atribut kategori. Dataset hepatitis membutuhkan operasi preprocessing dengan menggunakan transformasi $z$ score untuk memudahkan proses perhitungan dan cocok untuk data campuran (Marghny, 2011, Al Kindhi, 2019, Khotimah, 2020). Penelitian ini bertujuan untuk mengevaluasi pengaruh optimasi bobot pada K-Means dengan menggunakan algoritma genetika untuk memperbaiki data yang hilang pada pengelompokan data campuran.

\section{METODE PENELITIAN}

Proses hyrid imputasi memerlukan optimasi bobot karena data berupa imitasi yaitu luaran berasal dari imputasi, sehingga menghasilkan bias yang tinggi. Kami merangkum langkah-langkah dasar dari algoritma genetika dalam Algoritma 1. Dalam algoritma genetika, setiap individu (atau vektor solusi) dikodekan sebagai string bit biner atau vektor nilai riil, keduanya disebut sebagai kromosom. Representasi standar setiap individu adalah array biner bit, untuk memfasilitasi operasi crossover dan mutasi. Algoritma Optimasi bobot K-Means oleh GA jalannya sebagai berikut:

Algoritma : Fungsi $\mathrm{f}(\rightarrow \mathrm{x}), \rightarrow \mathrm{x}=\left(\mathrm{x}_{1}, \ldots, \mathrm{x}_{\mathrm{d}}\right)$ adalah $f$ untuk seleksi bobot.

1. Mulai, $\mathrm{t}=0$.

2. Inisialisasi parameter $K$-Means.

3. Inisialisasi bobot pusat cluster baru sesuai jumlah cluster $1 \ldots . \mathrm{k}$ 
4. Membangkitkan populasi awal kromosom bilangan riel $\mathrm{M}$ secara acak fungsi $\mathrm{f}(\mathrm{x})$

5. Mengevaluasi fungsi kebugaran (fitness) pada masing-masing individu dengan menggunakan MSE

6. Memilih individu terbaik dari populasi P0 (t) dengan pemilihan roda rolet.

a) Menerapkan Reproduksi crossover Pc dan mutasi $\mathrm{P}_{\mathrm{m}}$ untuk menghasilkan individu baru.

b) Ulangi sampai menghasilkan $\mathrm{M}$ individu.

c) Lakukan operasi GA di sub-populasi SPi (t) untuk mendapatkan pi individu terbaik $(t+1)$.

7. Ulangi untuk setiap $p_{i}$ individu $(t)$ untuk $(i=1$, $2, \ldots, \mathrm{M})$.

8. Hentikan proses jika kriteria terpenuhi ketika proses berjalan hingga generasi tertentu dengan error $<10 \%$.

9. Menghasilkan populasi baru $\mathrm{P}_{0}(\mathrm{t}+1)$ oleh individu pi $(t+1)$ dengan $\mathrm{i}=1,2, \ldots, \mathrm{M}$

10.Perbarui langkah waktu; $\mathrm{t} \leftarrow \mathrm{t}+1$. 11. Kembali ke langkah ke (6).

11.Simpan kromosom berisi bobot akhir terbaik

12.Imputasi data yang hilang untuk menghasilkan data yang lengkap

13.Hitung Error Data lengkap

14.Hentikan proses jika kriteria terpenuhi ketika proses berjalan hingga generasi tertentu dengan error $<10 \%$.

15.Jika kriteria tidak terpenuhi maka ulangi ke langkah 6

16. Selesai

\subsection{Menyiapkan Data Uji}

Algoritma GAKMI diawali dengan menginisialisasi parameter $K$-Means dengan menentukan pusat cluster, menentukan matriks $\varphi$ dan matrik t untuk mencari bobot (w). Menginisialisasi GA dengan menentukan populasi untuk kromosom dengan bobot yang sesuai dengan cluster, dengan pencarian MSE sampai iterasi epochs sesuai dengan Tabel 1.

Tabel 1. Kriteria Terminasi GAKMI

\begin{tabular}{ll}
\hline \multicolumn{1}{c}{ Kriteria } & \multicolumn{1}{c}{ Nilai } \\
\hline Batas Error Kriteria berhenti & $10 \%$ \\
Ukuran Populasi & 50 \\
Skema Pengkodean & Bilangan riel \\
Fungsi Fitness & Error K-Means \\
Crossover & Crossover 2 titik \\
Peluang Crossover & $0.5-1$ \\
Peluang Mutasi & $0.1-0.5$ \\
Mekanisme Seleksi & Roulette Wheel \\
Seleksi Survivor & Generational \\
& Replacement \\
\hline
\end{tabular}

Penggunaan parameter untuk pencarian dibatasi dibatasi sampai nilai fitness stabil dengan error tertentu, ukuran populasi awal 50, tingkat probabilitas mutasi $\mathrm{Pm}=0.2$ dan Probailitas Crossover $\mathrm{Pc}=0.8$. Kromosom GA akan digunakan untuk mewakili bobot awal dan update cluster pada KMI, $\mathrm{w}_{\mathrm{n}}$ mewakili sejumlah fitur dan $\mathrm{n}$ mewakili jumlah cluster. bit. Penggunaan set data dengan kromosom bilangan real untuk mewakili nilai bobot untuk imputasi data dengan tujuan menghasilkan data lengkap.

\subsection{Menyiapkan Data Uji}

Uji coba yang dilakukan adalah menggunakan data sintesis penyakit hepatitis dengan mengunduh dari UCI repository pada web site http:archive.ics.uci.edu/ml/datasets/Hepatitis. Verifik asi kinerja GAKMI menggunakan pyton 3. Data hepatitis terdiri jumlah total fitur adalah 19 dengan atribut campuran yang dominan mengandung data kategori yang berjumlah 14 fitur. Sehingga proses skala perlu dilakukan untuk memudahkan proses perhitungan.

Tabel 2. Teknik skala data hepatitis dengan atrbiut kategori

\begin{tabular}{|c|c|c|c|}
\hline No. & Atribut & Nilai Domain & Nilai Teknik Skala \\
\hline 1 & $\begin{array}{c}\text { Kelas/label } \\
\text { keputusan }\end{array}$ & Die, Live & Die $=1$, Live $=2$ \\
\hline 2 & Jenis Kelamin & $\begin{array}{l}\text { Laki-laki, } \\
\text { perempuan }\end{array}$ & $\begin{array}{l}\text { Laki-Laki }=1, \\
\text { Perempuan }=2\end{array}$ \\
\hline 3 & Steroid & No, Yes & $\mathrm{No}=0, \mathrm{Yes}=1$ \\
\hline 4 & Antiviral & No, Yes & $\mathrm{No}=0, \mathrm{Yes}=1$ \\
\hline 5 & Fatigue & No, Yes & $\mathrm{No}=0, \mathrm{Yes}=1$ \\
\hline 6 & Malaise & No, Yes & $\mathrm{No}=0, \mathrm{Yes}=1$ \\
\hline 7 & Anorexia & No, Yes & $\mathrm{No}=0, \mathrm{Yes}=1$ \\
\hline 8 & Liver Big & No, Yes & $\mathrm{No}=0, \mathrm{Yes}=1$ \\
\hline 9 & Liver Firm & No, Yes & $\mathrm{No}=0, \mathrm{Yes}=1$ \\
\hline 10 & $\begin{array}{c}\text { Spleen } \\
\text { Palpable }\end{array}$ & No, Yes & $\mathrm{No}=0, \mathrm{Yes}=1$ \\
\hline 11 & Spiders & No, Yes & $\mathrm{No}=0, \mathrm{Yes}=1$ \\
\hline 12 & Ascites & No, Yes & $\mathrm{No}=0, \mathrm{Yes}=1$ \\
\hline 13 & Varices & No, Yes & $\mathrm{No}=0, \mathrm{Yes}=1$ \\
\hline 14 & Histology & No, Yes & $\mathrm{No}=0, \mathrm{Yes}=1$ \\
\hline
\end{tabular}

Atribut campuran membutuhkan teknik skala dengan mengonversi data kategori yang memiliki nilai 'tidak' dan 'ya' menjadi 0 dan 1 . Variabel survival biner dinyatakan sebagai Kelas yang berupa resiko kematian 'Die' dan resiko hidup 'Live' telah dikodekan ke kategori dalam bentuk numerik (masing-masing 1 dan 2).

Pada kenyataanya data Hepatitis terdiri beberapa fitur yang mengandung nilai yang hilang, dengan prosentase yang berbeda-beda. Jumlah nilai yang hilang pada masing-masing fitur berbeda-beda sesuai Tabel 3 yaitu $\mathrm{SGOT}=4$, Alk Phosphate $=20$, Albumin $=15$, Protime $=40$, dan Bilirubin $=5$. Atribut dengan missing value diindikasikan oleh nilai "?".

\begin{tabular}{ccc}
\multicolumn{2}{c}{ Tabel 3. Variabel missing value pada data hepatitis } \\
\hline No. & Atribut & $\begin{array}{c}\text { Jumlah } \\
\text { Missing Value }\end{array}$ \\
\hline 1. & Kelas/Label Keputusan & 0 \\
2. & Umur & 0 \\
3. & Jenis Kelamin & 0 \\
4. & Steroid & 1 \\
5. & Antiviral & 0 \\
6. & Fatigue & 1 \\
7. & Malaise & 1 \\
8. & Anorexia & 1 \\
9. & Liver Big & 10 \\
\hline
\end{tabular}




\begin{tabular}{ccc}
\hline No. & Atribut & $\begin{array}{c}\text { Jumlah } \\
\text { Missing Value }\end{array}$ \\
\hline 10. & Liver Firm & 11 \\
11. & Spleen Palpable & 5 \\
12. & Spiders & 5 \\
13. & Ascites & 5 \\
14. & Varices & 5 \\
15. & Bilirubin: & 6 \\
16. & Alk Phosphate & 29 \\
17. & Sgot & 4 \\
18. & Albumin & 16 \\
19. & Protime & 67 \\
20. & Histology & 0 \\
\hline
\end{tabular}

Pengujian yang dilakukan dengan menyiapkan pre-processing terhadap data latih dengan mengubah data kategori menjadi numerik. Algoritma genetika menggunakan bilangan riel untuk menganti formulasi update bobot pada K-Means. Data yang digunakan sebanyak 155 data dengan 2 label (kelas). Selanjutnya melakukan pelatihan data dengan menggunakan data keseluruhan (full train) untuk algoritma genetika untuk menghasilkan kromosom akhir berupa bobot untuk proses imputasi pada K-Means, untuk menghasilkan data lengkap. Proses pengujian menggunakan data testing secara keseluruhan (full test) untuk mengelompokkan data sehingga diperoleh kinerja yang diinginkan.

\section{KAJIAN PUSTAKA}

\subsection{K-Means Imputation (KMI)}

Salah satu teknik heuristik paling populer untuk menyelesaikan clustering adalah K-Means untuk menyelesaikan masalah didasarkan pada skema iteratif sederhana untuk menemukan solusi minimal local (Binu, 2015). Algoritma K-Means diusulkan oleh J.B. MacQueen merupakan algoritma yang tidak diawasi bertujuan untuk meminimalkan indeks kesalahan kinerja cluster. Algoritma K-Means memiliki kelebihan dalam hal efisiensi dan kecepatan. Namun, algoritma ini sangat bergantung pada bobot awal dan nilai k. algoritma ini berdasarkan pada fungsi target selalu menggunakan metode gradien untuk mendapatkan ekstrem. Simulasi satu set dari $n$ titik data dalam ruang dimensi $d, R_{d}$, dan bilangan integer $k$. Perhitungan varian menggunakan jarak eucledian menentukan satu set titik $k$ di $R_{\mathrm{d}}$ disebut pusat, dengan meminimalkan jarak rata-rata kuadrat dari setiap titik data ke pusat terdekatnya (Viloriaa, 2019).

Pelatihan K-Means dilakukan pada setiap input vektor yang akan dipetakan pada cluster dengan bobot terdekat. K-Means menggunakan bobot pemenang dan semua tetangganya untuk diperbarui secara dinamis oleh fungsi objektif yag membutuhkan teknik optimasi sesuai dengan data input yang disediakan. Setiap perubahan interval waktu selama pembelajaran membutuhkan pembaruan bobot satu per satu secara dengan pengaturan parameter dinamis berulang kali untuk mendapatkan data output yang cocok dengan sistem target (Binu, 2015). K-Means Imputation (KMI) menggunakan bobot dari hasil pelatihan K-Means konvensional untuk proses pengisian data (Ahmad, 2007, Anwar, 2019). Sedangkan KMI untuk mengatasi kondisi data yang tidak lengkap dengan menerapkan perbaikan data pada tingkat preprosesing. Tahapan algoritma K-Means Imputation menunjukkan input vektor inisialisasi sebagai fitur input $x_{1}, x_{2}, x_{3}, \ldots x_{n}$ dan output untuk mendapatkan klaster $y_{1}, \quad y_{2}, \quad y_{3}, \ldots \quad y_{n}$ yang diinginkan.

1. Tentukan jumlah cluster $c$ dan centroid awal $\left(\mathrm{w}_{0}\right)$ secara random dari obyek-obyek data komplit yang tersedia sebanyak c cluster.

2. Hitung jarak terdekat pada setiap neuron keluaran untuk memasukkan data menggunakan jarak Euclidean:

$D_{i p}=\sqrt{\sum_{i=1}^{n}\left(x_{i j}-w_{p j}\right)}$

dengan

$D_{i p}$ : jarak antara obyek ke-1 dan centroid cluter ke

$x_{i j}$ : data pada obyek ke-i pad fitur ke

$w_{p j}$ : bobot centroid cluter ke pada fitur ke $\mathrm{n}$ banyaknya fitur

3. Kelompokkan setiap obyek berdasarkan jarak terdekat antara setiap obyek dengan masingmasing centroid.

4. Lakukan iterasi $(\mathrm{t})$, tentukan posisi centroid pada iterasi ke-t $(c)$ dengan rumus sebagai berikut:

$$
U_{i j}=\frac{1}{n} \sum_{i=1}^{n} x_{i j}
$$

Dengan:

$U_{p j}=$ centroid cluster $\mathrm{ke}-\mathrm{i}$ pada fitur ke-j

$\mathrm{n}=$ banyak/jumlah data yang menjadi anggota cluster ke-i

$x_{i j}$ : data pada obyek ke-i pada fiturl ke-j

4. Ulangi langkah 3 jika posisi $\mathrm{MSE}<10 \%$, Jika "Ya" maka proses perhitungan dihentikan dan dihasilkan kelompok data akhir.

5. Jika "Tidak", periksa langkah sebelumnya hingga tidak ada bobot pembaruan hingga mencapai kondisi berhenti sampai kesalahan terkecil dihasilkan sesuai batas nilai yang diinginkan. Seluruh bobot (Di) adalah jarak dicari terkecil, maka indeks bobot (Di) disebut pemenang. Nilai kesalahan terkecil melibatkan hasil prediksi yang lebih baik, dan sebaliknya.

6. Isi missing data dengan centroid yang sesuai dengan letak missing data berada. Hasil akhir $K$ Means dengan $x_{i p}=w_{i p}$ diperoleh dari hasil proses perhitungan jarak Euclid yang hasilnya berupa inisialisasi bobot (Khotimah, 2020). 


\subsection{Algoritma Genetika}

Golberg (1989) mengembangkan algoritma genetika untuk prosedur pencarian dan optimasi dengan menggunakan pengkodean serangkaian solusi masalah. Algoritma genetika mencari solusi dari kumpulan individu berupa populasi untuk memecahan masalah tersebut. Populasi terdiri sejumlah kromosom yang dipilih secara acak untuk mendapatkan solusi terbaik yang diinginkan (ElSawy, 2014).

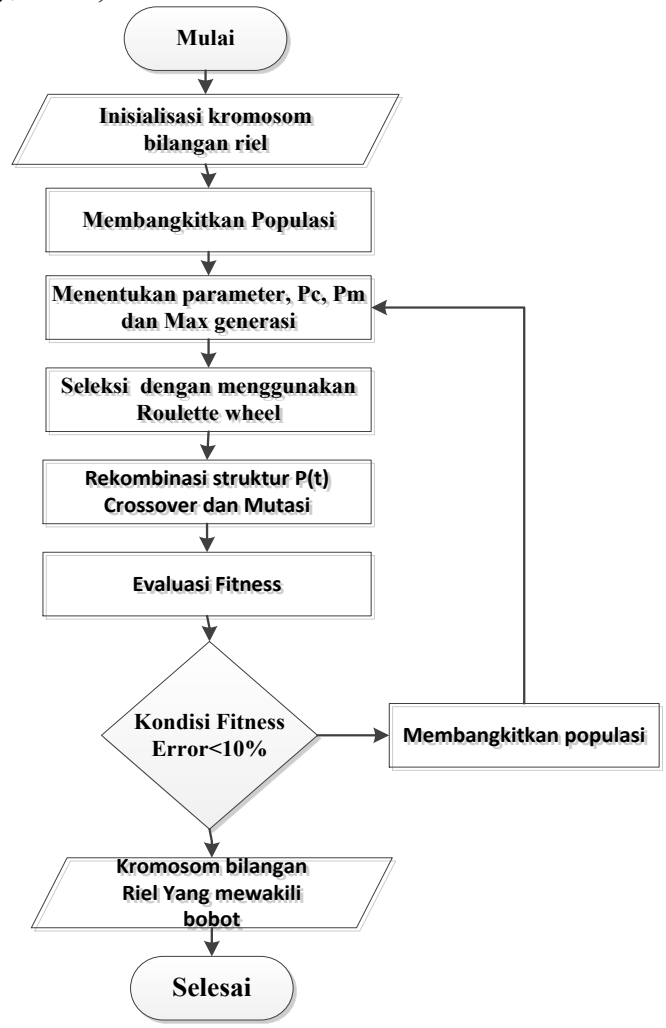

Gambar 1. Ilustrasi kinerja algoritma GA

Generasi baru ini dikenal sebagai keturunannya. Semakin tinggi kesesuaian anggota yang berbeda dalam populasi untuk bereproduksi ke generasi berikutnya sampai proses berlanjut menuju pencapaian yang konvergen (El-Sawy, 2014).

Gambar 1. Ilustrasi GA, generasi baru berasal dari operator reproduksi / seleksi, crossover, dan mutasi. Proses ini dilakukan berulang kali sehingga ditemukan jumlah kromosom yang cukup untuk membentuk generasi baru sebagai representasi dari solusi baru (Maulik, 2000, Ribelito, 2002). Kromosom akan dievaluasi dengan menggunakan pengukuran yang disebut kebugaran. Kromosom menggambarkan bobot yang terbaik berupa kromosom bilangan riel dalam populasi itu.

\subsection{Algoritma Genetika Untuk Pengaturan Bobot Dinamis}

Aturan pembaruan bobot dimulai dengan memungkinkan vektor bobot untuk mendekati area di sekitar solusi optimal dan cluster vektor bobot kemudian pindah ke pusat output cluster optimal $K$ -
Means (Kaczmarowski, 2015, Farag, 2015a, 2015b, Al Malki, 2016, Islam, 2020). Inisialisasi GA secara acak menghasilkan solusi awal yang ditetapkan dalam kromosom populasi yang mewakili bobot untuk setiap fitur ditunjukkan pada Gambar 2. Posisi gen dalam kromosom yang digunakan untuk itu adalah identifikasi fitur dan nilainya digunakan untuk mewakili bobot $K$-Means.

\begin{tabular}{|c|c|c|c|c|c|c|}
\hline & & G1 & & & $\ldots$ & Gn \\
\hline $\mathrm{C}_{11}$ & $\mathrm{C}_{12}$ & $\mathrm{C}_{13}$ & $\mathrm{C}_{14}$ & $\mathrm{C}_{15}$ & $\ldots$ & $\overline{C_{m n}}$ \\
\hline$W_{11}$ & $W_{12}$ & $W_{13}$ & $W_{14}$ & $W_{15}$ & $\ldots$ & Wmn \\
\hline
\end{tabular}

Pembobotan pada K-Means untuk fitur berdasarkan jumlah cluster yang ditetapkan. Setiap kromosom mewakili bobot setiap seri fitur pada seri waktu tertentu. Optimalisasi untuk menemukan vektor bobot terbaik yang terkait dengan $\mathrm{w}_{\mathrm{j}}$ untuk mewakili $1 \mathrm{xN}$ pada setiap elemen fitur (Zeebaree, 2017, Khotimah, 2020).

$$
\begin{aligned}
& w_{m n}=\left(w_{11}, w_{12}, \ldots, w_{m n}\right) \\
& \sum_{j=1}^{m} w_{j}=1, w_{j} \geq 0, \quad j=1,2, \ldots, m
\end{aligned}
$$

Kromosom GA akan digunakan untuk mewakili bobot awal klaster KMI. Gene berisi satu set bobot pada semua fitur variabel, ketika $\mathrm{m}$ mewakili sejumlah fitur dan $\mathrm{n}$ mewakili jumlah cluster. Kromosom terus berubah menjadi generasi populasi baru melalui proses seleksi, crossover, dan mutasi. Proses tersebut berevolusi menggantikan seluruh kromosom dalam populasi. Kromosom terdiri dari sejumlah gen yang menunjukkan bobot yang akan dialokasikan untuk masing-masing fitur-fitur.

$$
\begin{aligned}
& \text { fitness }=\frac{1}{M S E+h}, 0 \leq h \leq 1 \\
& M S E=\frac{\sum_{i=1}^{n}\left(Y_{i}-Y_{i}\right)^{2}}{n}
\end{aligned}
$$

dengan

$$
\begin{aligned}
& Y_{i}=\text { target } \\
& \widehat{Y}_{i}=\text { prediksi }
\end{aligned}
$$

GA menggunakan fungsi kebugaran untuk memandu kinerja GAKMI untuk kasus yang harus diselesaikan. MSE digunakan secara langsung sebagai fungsi kebugaran (fitness), kesesuaian untuk pemilihan proporsional harus meningkatkan efisiensi ke kondisi yang konvergen. Indeks MSE semakin kecil berarti semakin optimal, dengan iterasi tertentu. kromosom pertama di kombinasikan bagian kedua dari kromosom kedua menjadi keturunan pertama. Sedangkan bagian kedua kromosom pertama di kombinasikan dengan bagian pertama kromosom kedua menjadi keturunan kedua. Hal ini dilakukan pada masing-masing pasangan induk yang akan di Crossover (Rahman, 2014).

Proses imputai dilakukan pada data $x_{i}$ membutuhkan nilai kelas $c_{k}$ dan nilai bobot atribut 
$w_{i j}$ Prosedur pengisian nilai yang hilang berupa kumpulan data $X_{i}$ yang terdiri $x_{m}$ nilai yang hilang dan $x_{c}$ tanpa nilai yang hilang. Vektor bobot urutan di setiap $i=1,2, \ldots, j$ pada KMI akan dimasukkan kedalam data berdasarkan kelas dan letak kriteria yang sesuai pada data yang hilang $X_{i r}=\left(c_{i}, w_{j}\right)$ (Khotimah, 2020).

$1 \leq w_{i j} \leq p$, if $w_{i j}=x_{i m}(i, m) \in N_{m}$

\section{HASIL DAN PEMBAHASAN}

Kromosom GA akan digunakan berupa bobot awal pada KMI. Gen berisi satu set bobot pada semua fitur variabel, ketika $m$ mewakili sejumlah fitur dan n mewakili jumlah cluster. Skenario ujicoba menggunakan satu set kumpulan data memiliki 19 atribut dan jumlah cluster yang diharapkan adalah 2. Gen berisi 19 kromosom dengan jumlah populasi 50. Kromosom berupa bilangan real untuk dengan mudah mewakili nilai bobot imputasi aktual. bobot digunakan untuk uji validasi KMI.

Proses imputasi KMI untuk data missing value dengan imputasi ganda berdasarkan nilai k untuk replika. Contoh data hepatitis pada 4 fitur dan 10 baris pertama terdiri fitur yang mengandung nilai yang hilang dengan prosentase hamper sama kurang lebih 5\%. Fitur tersebut adalah Spleen Palpable, Spiders, Ascites, Varices. Hasil akhir learning KMI pada fitness mendekati 0 , misalnya pada iterasi 420 menghasilkan bobot centroid dan anggota cluster 1 yaitu obyek 1, 2, 4, serta cluster 2 yaitu obyek 3,5 , $6,7,8,9,10$.

$$
\begin{gathered}
w_{420}^{1}=(-0.227, ; 1.342 . ; 1.44 ; 0.642) \\
w_{420}^{2}=(-0.302, ;-0.879 . ;-0.445 ;-0.322)
\end{gathered}
$$

Tabel 3. dan Tabel 4. Proses pengisian data misalnya $x_{m i s}\left(x_{13}, w_{31}\right)$ artinya data yang hilang pada fitur ke 3 dan kelas 1. Kemudian mengisi missing data dengan centroid yang sesuai dengan letak missing data berada yaitu

$$
\begin{gathered}
x_{m i s}\left(x_{11}, w_{31}\right)=1.443, x_{m i s}\left(x_{31}, w_{12}\right)= \\
-0.302 ; x_{m i s}\left(x_{42}, w_{21}\right)=1.342 ; x_{m i s}\left(x_{71}, w_{12}\right)= \\
-0.302 ; \operatorname{dan} x_{m i s}\left(x_{92}, w_{22}\right)=-0.879 .
\end{gathered}
$$

Proses replika dilakukan dengan melakukan pengisisan data secara berulang. Penggunaan replika untuk mengetahui tingkat imputasi keberapa nilai data mendekati aslinya. Untuk mengukur kinerja algoritma pada suatu data setelah proses imputasi, maka dilakukan pengujian dengan menggunakan MSE sesuai Tabel 5.

Tabel 3. Data Preimputasi

\begin{tabular}{lllll}
\hline No. User & $\begin{array}{l}\text { Spleen } \\
\text { Palpable }\end{array}$ & Spiders & Ascites & Varices \\
\hline 1. & -0.272 & 0.541 & $\mathrm{NaN}$ & 1.129 \\
2. & -0.272 & 0.360 & 0.073 & 1.228 \\
\hline
\end{tabular}

\begin{tabular}{lllll}
\hline No. User & $\begin{array}{l}\text { Spleen } \\
\text { Palpable }\end{array}$ & Spiders & Ascites & Varices \\
\hline 3. & $\mathrm{NaN}$ & 1.535 & -0.073 & -0.928 \\
4. & -0.791 & $\mathrm{NaN}$ & -0.073 & -0.281 \\
5. & -0.791 & -0.612 & -1.622 & -0.271 \\
6. & -0.791 & -0.287 & -1.622 & 1.427 \\
7. & $\mathrm{NaN}$ & 0.175 & -1.622 & 1.342 \\
8. & -0.272 & -0.867 & -0.073 & -1.32 \\
9. & -0.272 & $\mathrm{NaN}$ & -1.622 & 0.819 \\
10. & -0.791 & -1.384 & -1.622 & 0.239 \\
\hline
\end{tabular}

Tabel 4. Data Hasil Pascaimputasi

\begin{tabular}{ccccc}
\hline No. User & $\begin{array}{c}\text { Spleen } \\
\text { Palpable }\end{array}$ & Spiders & Ascites & Varices \\
\hline 1. & -0.272 & 0.541 & 1.443 & 1.129 \\
2. & -0.272 & 0.360 & 0.073 & 1.228 \\
3. & -0.302 & 1.535 & -0.073 & -0.928 \\
4. & -0.791 & 1.342 & -0.073 & -0.281 \\
5. & -0.791 & -0.612 & -1.622 & -0.271 \\
6. & -0.791 & -0.287 & -1.622 & 1.427 \\
7. & -0.302 & 0.175 & -1.622 & 1.342 \\
8. & -0.272 & -0.867 & -0.073 & -1.32 \\
9. & -0.272 & -0.879 & -1.622 & 0.819 \\
10. & -0.791 & -1.384 & -1.622 & 0.239 \\
\hline
\end{tabular}

Tabel 5. Nilai MSE berdasarkan proses replika

\begin{tabular}{llllll}
\hline No. & Repl 1 & Repl 2 & Repl 3 & Repl 4 & Repl 5 \\
\hline $\mathrm{K}=2$ & 0,302 & 0,605 & 0,532 & 0,875 & 0,466 \\
$\mathrm{~K}=2$ & 0,323 & 0,052 & 0,932 & 0,704 & 0,766 \\
$\mathrm{~K}=3$ & 0,092 & 0,502 & $\mathbf{0 , 2 1 5}$ & 0,855 & $\mathbf{0 , 0 4 4}$ \\
$\mathrm{K}=4$ & 0,203 & 0,456 & 0,879 & 0,954 & 0,659 \\
$\mathrm{~K}=5$ & 0,695 & 0,367 & 0,667 & 0,674 & 0,586 \\
\hline
\end{tabular}

Tabel 5 menunjukkan hasil proses replika pada setiap imputasi pada fitur yang terdapat missing data. Hasil imputasi missing data menggunakan metode Algoritma GAKMI dengan 2 cluster menghasilkan nilai MSE pada replika ke- $1,2, \ldots 5$ bahwa replika ke-3 dan ke-5 pada $K=3$ memberikan nilai MSE yang lebih kecil dibandingkan yang lain. Pada setiap replika menghasilkan MSE yang berbeda-beda, karena nilai bobot untuk mengisi nilai yang hilang bervariasi.

Gambar 3. Penggunaan GAKMI dengan perbedaam ukuran populasi menunjukkan nilai MSE yang sangat fluktuatif. Semakin tinggi populasinya, semakin kecil nilai kesalahan yang dihasilkan. Semakin tinggi populasi mengakibatkan jumlah generasi meningkat dan tingkat kesalahan yang dihasilkan semakin kecil.

Tabel 6. Perbandingan populasi terhadap waktu eksekusi

\begin{tabular}{lcccc}
\hline Parameter & $\begin{array}{c}\text { Perubahan } \\
\text { Jumlah } \\
\text { Populasi }\end{array}$ & Fitness & $\begin{array}{c}\text { Iterasi } \\
\text { fitness } \\
\text { akhir }\end{array}$ & $\begin{array}{c}\text { Waktu } \\
\text { Eksekusi } \\
\text { (second) }\end{array}$ \\
\hline $\mathrm{Pc}=0,5$ & 50 & 0,928 & 603 & 834 \\
$\mathrm{Pm}=0,5$ & 100 & 0,823 & 721 & 1174 \\
$\mathrm{Pc}=0,6$ & 50 & 0,864 & 425 & 762 \\
$\mathrm{Pm}=0,4$ & 100 & 0,706 & 676 & 1478 \\
$\mathrm{Pc}=0.7$ & 50 & 0,880 & 506 & 706 \\
$\mathrm{Pm}=0,3$ & 100 & 0,914 & 639 & 1059 \\
\hline
\end{tabular}




\begin{tabular}{lcccc}
\hline Parameter & $\begin{array}{c}\text { Perubahan } \\
\text { Jumlah } \\
\text { Populasi }\end{array}$ & Fitness & $\begin{array}{c}\text { Iterasi } \\
\text { fitness } \\
\text { akhir }\end{array}$ & $\begin{array}{c}\text { Waktu } \\
\text { Eksekusi } \\
\text { (second) }\end{array}$ \\
\hline $\mathrm{Pc}=0,8$ & 50 & 0,671 & 576 & 322 \\
$\mathrm{Pm}=0,2$ & 100 & 0,891 & 821 & 1421 \\
$\mathrm{Pc}=0,9$ & 50 & 0,915 & 853 & 301 \\
$\mathrm{Pm}=0,1$ & 100 & 0,588 & 186 & 811 \\
\hline
\end{tabular}

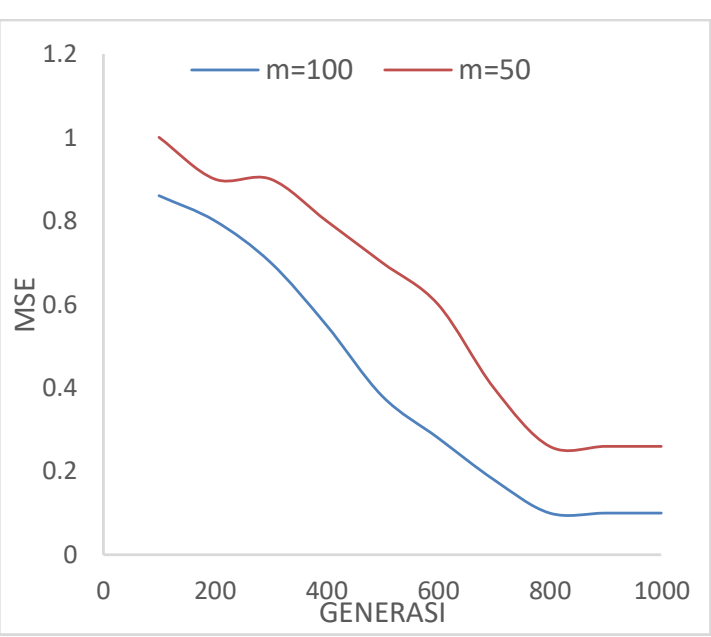

Gambar 3. Perbandingan pengaruh populasi terhadap fitness

Tabel 6 menunjukkan hasil pengujian berdasarkan penggunaan parameter dengan perbedaan populasi, parameter Pc dan Pm. Perubahan nilai probabilitas crossover dan mutasi menghasilkan nilai fitness yang bervariasi. Nilai probabilitas crossover terbaik antara 0.5 sampai 1 . Semakin besar peluang crossover maka perubahan data semakin tinggi. Sehingga data berpeluang besar mendekati aslinya. Sedangkan nilai probabilitas mutasi berkisar 0.5-0.1, karena semakin kecil mutasi maka perubahan kecil. Algoritma GAKMI berkerja baik dalam proses estimasi bobot dengan nilai MSE yang kecil. GA mengeksplorasi nilai hak untuk mengatur bobot untuk memeriksa setiap generasi, solusinya akan meningkat. Peningkatan kualitas kromosom di semua kovariat sangat signifikan untuk menangani data yang mempunyai fitur mayoritas kategori.

Tabel 7. Uji korelasi r dan uji t berpasangan data Hepatitis

\begin{tabular}{cccccccc}
\hline No & \multicolumn{2}{c}{ KMI } & \multicolumn{2}{c}{ GAKMI } & \multicolumn{2}{c}{ Mean Imp } \\
\hline $\mathrm{k}$ & $\mathrm{t}$ & $\mathrm{r}$ & $\mathrm{t}$ & $\mathrm{r}$ & $\mathrm{t}$ & $\mathrm{r}$ \\
\hline 2 & 0,564 & 0,202 & 0,392 & 0,526 & 0,046 & $-0,235$ \\
3 & $-0,298$ & 0.523 & 0,002 & 0,574 & 0,044 & $-0,014$ \\
4 & 0,195 & $-0,268$ & 0,291 & 0,129 & 0,658 & $-0,087$ \\
5 & 0,86 & $-0,574$ & 0,063 & 0,064 & 0,564 & $-0,096$ \\
\hline \multicolumn{3}{c}{ Signifikan pada $\alpha=0.05$} \\
\end{tabular}

Uji korelasi digunakan untuk menguji tingkat seberapa jauh nilai pengganti imputasi mendekati dengan nilai aslinya. Tabel 7 menunjukkan imputasi yang baik adalah ketika nilai $r$ positif, yang berarti metode imputasi cocok untuk mengganti nilai data yang hilang. Nilai $r$ yang mendekati 1 yang paling baik untuk teknik imputasi. Tabel 7 menunjukkan tingkat signifikan (lebih besar dari $\alpha=0.05$ ) sehingga
$\mathrm{H}_{0}$ diterima. Algoritma GAKMI selalu memberikan nilai $\mathrm{r}$ lebih besar dibanding metode Mean, dan KMI itu sendiri yang tanpa optimasi. Algoritma GAKMI dengan nilai $r$ dominan positif karena dapat memilih nilai replika yang mendekati nilai aslinya dengan MSE terkecil, sehingga GAKMI menunjukkan hasil yang lebih baik dibanding metode metode imputasi lainnya.

\section{KESIMPULAN}

GA memilih bobot yang tepat akan memengaruhi pengelompokan K-Means, yang menghitung jarak terkecil antara data dengan pusat klaster (centroid). Pengaruh nilai $k$ pada $K$-Means menunjukkan bahwa MSE semakin tinggi. Hasil penelitian GAKMI menunjukkan perbedaan signifikan dalam nilai mean square error (MSE) pada setiap generasi dan jumlah populasi GA, nilai MSE terbesar adalah 0,928 dan yang terkecil adalah 0,588. Sedangkan pada pengujian kecocokan imputasi nilai korelasi (r) pada GAKMI cenderung positif, artinya GAKMI cenderung lebih unggul dibandingkan dengan KMI dan Means yang cenderung nilai $r$ nya negatif. Karena GAKMI menggunakan pemilihan bobot yang sesuai dan mendekati nilai sebenarnya..

\section{DAFTAR PUSTAKA}

AL KINDHI, B., SARDJONO, T. A., PURNOMO, M. H., VERKERKE, G. J., 2019. Hybrid Kmeans, Fuzzy C-Means, And Hierarchical Clustering for DNA Hepatitis C Virus Trend Mutation Analysis. Expert Systems with Applications, Issue 121, 1 May, pp. 373-381.

A ACUNA, E, AND RODRIGUES C., 2004. The Treatment of Missing Values and its Effect is the Classifier Accuracy. Proceedings of the Meeting of the International Federation of Classification Sociaties (IFCS), 15 Juli 2004.

AL MALKI, A., MOHAMED M. RIZK1, M. M., ELSHORBAGY, M. A., MOUSA, A. A., 2016. Hybrid Genetic Algorithm with K-Means for Clustering Problems, Open Journal of Optimization, issue 5, pp. 71-83.

ANWAR, T., SISWANTINING, T., SARWINDA, D., SOEMARTOJO, S. M., BUSTAMAM, A., A study on missing values imputation using K-Harmonic means algorithm: Mixed datasets. AIP Conference Proceedings, issue 2202, 020038 (2019), pp.1-10

BINU, D. 2015. Cluster Analysis Using Optimization Algorithms with Newly Designed Objective Functions. Expert Systems with Applications, 42(14), pp.5848- 5859.

CHEHOURI, A., R. YOUNES, R., KHODER, J., PERRON, J., ILINCA, A., 2017. A Selection Process for Genetic Algorithm Using 
Clustering Analysis. Algorithms, 10(123), pp. $1-15$

DAVEY, A, And SAVLA J., 2010. Statistical Power Analysis with Missing Data. New York: Taylor and Francis Group.

ENDERS, C. K., 2014. Applied Missing Data Analysis [monograph online]. New York: The Guilford Press.

EL-SAWY, A. A., HUSSEIN, M. A., ZAKI, E.M. AND MOUSA, A. A., 2014. An Introduction to Genetic Algorithms: A Survey A Practical Issues. International Journal of Scientific \& Engineering Research, 5(1), pp.252.

FARAG, M.A., EL-SHORBAGY, M.A., ELDESOKY, I.M., EL-SAWY, A.A. MOUSA, A.A., 2015. Genetic Algorithm Based on $K$ Means-Clustering Technique for MultiObjective Resource Allocation Problems. British Journal of Applied Science \& Technology, 8(1), pp. 80-96. http://dx.doi.org/10.9734/BJAST/2015/16570

FARAG, M. A., EL-SHORBAGY, M.A., ELDESOKY, I. M., EL-SAWY, A.A., MOUSA, A. A., 2015. Binary-Real Coded Genetic Algorithm Based K-Means Clustering for Unit Commitment Problem. Applied Mathematics, 6(11), pp.1873-1890. http://dx.doi.org/10.4236/am.2015.611165

HAN, J. AND KAMBER, M. 2000. Data Mining: Concepts and Techniques. Morgan Kaufmann, San Francisco.

IZZAH, A., AND HAYATIN, N., 2013. Imputasi Missing Data Menggunakan Algoritma Pengelompokan Data K-Harmonic Means. Seminar Nasional Matematika dan Aplikasinya (SNMA), 21 September.

ISLAM, M. T. P., BASAK, K., BHOWMIK, P., KHAN, M., 2020. Data Clustering Using Hybrid Genetic Algorithm with k-Means and k-Medoids Algorithms. 2019 23rd International Computer Science and Engineering Conference (ICSEC), IEEE Xplore. Phuket, Thailand, 30 January 2020.

KACZMAROWSKI, A., YANG, S., SZLUFARSKA, I. AND MORGAN, D. 2015. Genetic Algorithm Optimization of Defect Clusters in Crystalline Materials. Computational Materials Science, 98(1), pp. 234-244.

KHOTIMAH, B. K., MISWANTO, SUPRAJITNO, H., 2020. Optimization of Feature Selection Using Genetic Algorithm in Naïve Bayes Classification for Incomplete Data, International. Journal of Intelligent Engineering and Systems (IJIES), Issue.13, 2020, pp.334-343.

KHOTIMAH, B. K., IRHAMNI, F., SUNDARWATI, T., 2016. A Genetic Algorithm for Optimized Initial Centers K-
Means Clustering in SMEs. Journal of Theoretical and Applied Information Technology, 15 August, 90(1), pp. 23-30

LI D., DEOGUN J., SPAULDING W., SHUART B. Toward Missing Data Imputation: Study of Fuzzy K-Means Clustering Method. Proceedings 4 th International Conference. 2004 jun 1.

MAULIK, U. AND BANDYOPADHYAY, S. 2000. Genetic Algorithm Based Clustering Technique. Pattern Recognition, 33 (9), pp $1455-1465$.

MARGHNY, M. H., EL-AZIZ, R. M. A., TALOBA, R. M. A., 2011. An Effective Evolutionary Clustering Algorithm: Hepatitis C Case Study. International Journal of Computer Applications, 34(6), pp. 1-6.

RAHMAN, M.A. AND M.Z. ISLAM, 2014. A Hybrid Clustering Technique Combining a Novel Genetic Algorithm with K-Means. Knowledge-Based Systems, 71, p. 345-365.

T. Mahboob, A. Ijaz, A. Shahzad, and M. Kalsoom, Handling Missing Values in Chronic Kidney Disease Datasets Using KNN, K-Means and K-Medoids Algorithms. International Conference on Open Source Systems and Technologies (2018).

VILORIAA A., LEZAMA, O. B. P., 2019. Improvements for Determining the Number of Clusters in k-Means for Innovation Datab ases in SMEs. Procedia Computer Science, Issue 151, pp.1201-1206.

ZEEBAREE, D. Q., HARON, H., ABDULAZEEZ, A. M., AND SUBHI R. M., 2017. Combination of K-Means Clustering with Genetic Algorithm: A Review. International Journal of Applied Engineering Research, 12 (24), pp. 14238- 14245. 